\title{
Determinants of agricultural technology adoption: A case study in the floricultural sector of Lam Dong province and Ho Chi Minh City, Vietnam
}

\author{
TRAN TIEN KHAI ${ }^{a,}{ }^{,}$, PHAM THI PHUONG DUNG ${ }^{a}$ \\ ${ }^{a}$ University of Economics Ho Chi Minh City
}

\begin{abstract}
A R T I C L E I N F O
A B S T R A C T

Received: Mar 18, 2019

Revised: Oct 9, 2019

Accepted: Nov 6, 2019

Available online

JEL classification:

Q16, Q18, N55

Keywords

Floriculture;

Technology adoption; Probit model.

Floriculture is an important agricultural sector of Lam Dong province and Ho Chi Minh City, Vietnam. The favorable climate conditions of Lam Dong province have led to the strong development of the floriculture sector, while high demand due to lifestyle changes in Ho Chi Minh City promises a potential market for the cut orchid industry. The adoption of modern technology is vitally important for small-scale producers because it not only improves the quality but also increases the yield of flower production. However, very little research has been conducted on the adoption of technology in the floriculture industry at the farm level. A sample of 228 producers was therefore collected in Lam Dong province and Ho Chi Minh City in 2018 to investigate the current status of, and influential factors for, technology adoption by floriculture producers in the South of Vietnam. Conditional mixedprocess probit models were applied to examine decisions on the adoption of technologies associated with greenhouse, irrigation and seedlings in floriculture. The results reveal that farmers have strong preferences in terms of modern floriculture technologies and that demographic characteristics such as gender, age, education and income, as well as farm size, learning process, farmers' perception of
\end{abstract}

\footnotetext{
* Corresponding author.

Email: khaitt@ueh.edu.vn (Tran Tien Khai), dung.ptp@vnp.edu.vn (Pham Thi Phuong Dung).

Please cite this article as: Tran, T. K., \& Pham, T. P. D. (2019). Determinants of agricultural technology adoption: A case study in the floricultural sector of Lam Dong province and Ho Chi Minh City, Vietnam. Journal of Asian Business and Economic Studies, 26(S02), 25-46.
} 
technology and market information are the key determinants of technology adoption in floriculture.

\section{Introduction}

Although agriculture is an important sector in Vietnam's economy, it has been facing various difficulties due to small-scale production, the low level of technology adoption, uncontrolled quality, and high production costs. Improvement of the competitiveness of the agricultural sector is very urgent, and to achieve such improvement, the application of advanced technology in agriculture is one of the key factors. Technology adoption in agriculture is considered one of the most important solutions to increase the productivity and quality of agricultural products, meet market standards and thus achieve higher added value for producers.

Floriculture is the most progressive sector in terms of the application of state-of-the-art technology in Vietnam. Lam Dong province is a center of floriculture and has diverse levels of technology adoption. With favorable natural conditions, Lam Dong has more than 8,000 hectares of land under floriculture production, with producers on 2,782 hectares applying advanced agricultural technology (Statistical Office of Province Lam Dong, 2018). In Ho Chi Minh City, the suburban area is traditionally a food belt, but this has been narrowed down due to rapid urbanization in recent years. The demand of urban residents is gradually shifting from basic foods to high value foods, decorative flowers and ornamental plants. By 2015, 2,250 hectares of Ho Chi Minh City had been converted from food crops to decorative flowers and ornamental plants, of which cut orchids accounted for approximately 300 hectares. The adoption of new floriculture species and production technology is observed in both locations. Such adoption is an effective way of increasing agricultural productivity and farmers' income, because it helps adopters produce new products to meet the rising demand of consumers.

Several previous studies on agricultural technology adoption have been conducted in Vietnam, but they have focused on aspects such as the adoption of sustainable agriculture practices in banana production (Van Thanh \& Yapwattanaphun, 2015), the adoption of direct-seeding mulch-based cropping systems on mountainous slopes (Affholder et al., 2010), integrated shrimp mangrove aquaculture (Joffre et al., 2015), the effect of the land titling policy on the adoption of soil conservation technologies (Saint-Macary et al., 2010), and agroforestry adoption (Simelton et al., 2017). However, few empirical studies have been conducted on technology adoption in Vietnamese floriculture. Consequently, there is a gap in the knowledge on the status of technology adoption and its determinants in floriculture at farm level in Vietnam. The current study aims to: 1) Describe the status of technology adoption in floriculture; and 2) examine the determinants of technology adoption by small- 
scale floriculture producers in Vietnam. The findings might contribute to a better understanding of floriculture technology adoption in Vietnam and could provide detailed insights into public policy design that will promote the floriculture sector and thus increase the income of floriculture farmers.

\section{Literature Review}

Agricultural technology is introduced as a technology package that includes several components. While components of a technology package may complement other components, it is possible that some components are used independently. Producer can either select a full package of technology or just one or a few elements for their farming activity. Technology is usually transferred to users through adoption and diffusion processes. Technology adoption is known as an individual behavior to employ a new technology, while technology diffusion is defined as a collective behavior of individuals or a community. Diffusion is also understood as an imitation process among farmers, and this process demonstrates how farmers learn about new agricultural technology.

Feder et al. (1982) have provided a literature review of decision-making on the adoption and use of farmers' technology and have argued that a farmer's decision is based on the expected utility maximization assumption with respect to the availability of land, credit and other constraints. Technology decision-making behavior reflects choice in the context of imperfect information. In other words, decision-makers face uncertainty, and thus their decisions depend on their risk attitude. The review by Feder et al. (1982) reported that the main determinants of technology adoption include human capital, risk aversion, labor availability, farm size, concerns about labor, supply of additional input materials, access to information, and availability of credit. Sunding and Zilberman (2001) have found that technology adoption is affected by numerous factors such as risk and uncertainty of technology, the irreversible characteristic of investment, optimal timing of technology adoption, learning issues, adoption time, institutional constraints including credit supply, tenure mechanism, complementary inputs and infrastructure, input subsidies, output price supports, taxation, trade liberalization and macroeconomic policies, and environmental policies.

The theoretical determinants of agricultural technology adoption can be classified into the following groups: 1) Psychological factors, 2) characteristics of technology, 3) economic factors, 4) institutional factors, 5) socio-economic factors of farmers or individuals, and 6) community factors. Joffre et al. (2015) have argued that both external and internal drivers influence farmers' decisions to apply an integrated mangrove-shrimp system. The former includes the market and value chain, the governance and regulatory framework, production and bio-physical conditions. The latter includes market and trade organization, production systems and internal bio-physical conditions. Meanwhile, Van Thanh and Yapwattanaphun (2015) have used a two-category division method to analyze the socio-economic characteristics of farmers and behavioral control factors such as the perceived characteristics 
of new technologies and the perceived access to resources. Affholder et al. (2010) have concluded that labor and cash constraints, information availability, technical adjustment and subsidies from the government affect farmers' adoption of direct-seeding mulch-based cropping systems in the mountainous areas of Vietnam.

The characteristics of technology affect technology adoption, especially level of complexity and compatibility with the farmers' ability (CIMMYT Economics Program, 1993; Liu et al., 2008; Mazvimavi \& Twomlow, 2009; Yengoh et al., 2009).

Economic factors also influence technology adoption. Farms of a large size facilitate the adoption of technology due to economies of scale (CIMMYT Economics Program, 1993; Maonga et al., 2013; Mazvimavi \& Twomlow, 2009; Saka \& Lawal, 2009; Sunding \& Zilberman, 2001; Tiwari et al., 2008; Yengoh et al., 2009). Off-farm income also has a positive impact on the adoption rate of technology because it helps households to diversify their income sources, and hence reduce risks (Kassa et al., 2014). An increase in market demand for products using new technology promotes the ability to adopt technology (CIMMYT Economics Program, 1993). The availability of a strong inputs market will increase farmers' ability to adopt technology (CIMMYT Economics Program, 1993; Sunding \& Zilberman, 2001). The shorter the distance to the nearest market, the more likely it is that farmers will adopt technology (Kansiime et al., 2014; Kassa et al., 2014; Simtowe et al., 2012).

Household socio-economic characteristics strongly influence farmers' technology adoption. A strong educational foundation is positively related to technology adoption. Education helps farmers to receive better technical and economic information and thus enables them to respond to technical recommendations at different educational levels (CIMMYT Economics Program, 1993; Ebojei et al., 2012; Maonga et al., 2013; Saint-Macary et al., 2010; Tiwari et al., 2008; Liu et al., 2008). However, the opposite relationship between education and technology adoption was found in the case of biofuel crops (Cheteni et al., 2014).

The age and experience of farmers are also influential factors (CIMMYT Economics Program, 1993; Ebojei et al., 2012; Gebregziabher et al., 2014; Saint-Macary et al., 2010). Men have been found to have stronger decision-making power than women, possibly due to their higher risk-taking nature (Baffoe-Asare et al., 2013; CIMMYT Economics Program, 1993; Cheteni et al., 2014; Gebregziabher et al., 2014; Kansiime et al., 2014; Kassa et al., 2014; Mazvimavi \& Twomlow, 2009). The scale of human resources impacts on technology adoption, especially with respect to labor-intensive or labor-saving technology, depending on the constraints of labor market restrictions (Cheteni et al., 2014; Baffoe-Asare et al., 2013; Kansiime et al., 2014). In addition, the richer the household, the easier it is to adopt technology because of a greater capacity to make the initial investment, a stronger ability to take risk prevention measures, and better access to information, extension services and technology services (CIMMYT Economics Program, 1993; Sarker et al., 2009, Liu et al., 2008).

Based on the above literature review, the determinants of technology adoption can be simply organized into three groups of factors: 1) The innovation diffusion, 2) the economic 
constraints, and 3) the psychological factors, in other words perceptions and attitudes. This study attempts to cover the role of economic constraints and the perceptions of small-scale floriculture producers on technology adoption. The concept of advanced agricultural technology used in this study distinguishes between traditional and modern technologies, such as the use of green-house technology, the application of new irrigation systems, and new and/or high-quality seeds and varieties.

\section{Methodology}

\subsection{Econometric approach}

The farmer's adoption decision is based on a random utility framework (Adesina \& Zinnah, 1993; Ralm \& Huffman, 1984; Wollni et al., 2010). The adoption of a certain $j^{\text {th }}$ technology is assumed to maximize a non-observable underlying utility function:

$$
U_{j i}=V_{i}\left(a_{j} X_{i}\right)+e_{j i} \text { for } j=0,1 \text { or } 1,2,3 ; i=1, \ldots, n .
$$

where $V_{i}$ is the observed portion of the farmer's utility function, is expressed as a function of a vector of farm and farmer-specific characteristics of the adopter (e.g. farm size, age, gender, education, credit, experience, etc.) and attributes associated with the specific technology (e.g. yield, quality, price, cost, etc.), and a vector of parameters to be estimated, $a_{j}$. The unobserved portion of the utility function is represented by an error term $e_{j i}$.

\subsubsection{Greenhouse adoption}

In this study, the greenhouse system, irrigation system and choice of seedling type are three main individual components of technology adopted by producers.

The greenhouse adopters are divided into two groups. Farmers can choose a simple greenhouse or adopt the modern one. The decision whether to apply a modern greenhouse in relation to a simple one is based on a comparison of marginal net benefits of one against the other. The farmer $i$ chooses to adopt the modern if the net benefits of adopting it $(j=1)$ exceed that of the simple one $(j=0)$. In other words, the $i^{\text {th }}$ farmer chooses the modern greenhouse if the latent variable $Y_{i}^{*}=U_{1 i}-U_{0 i}>0$. We may write the following equation in the unobserved variable $Y_{i}^{*}$ :

$$
Y_{i}^{*}=\beta_{0}+\beta_{1} X_{1 i}+\ldots+\beta_{k} X_{k i}+u_{i}=X_{i} \beta+\varepsilon_{i}
$$

where $X_{i}$ is the $n \times k$ matrix of the explanatory variables, $\beta=a_{1}-a_{0}$ is a $k \times 1$ vector of parameters to be estimated, and $\varepsilon_{i}=e_{1 i}-e_{0 i}$ is the error term. The observed variables are $Y_{i}=1$ when $Y_{i}^{*}>0 ; Y_{i}=0$ when $Y_{i}^{*} \leq 0$ for the $i^{\text {th }}$ farmer.

By using equation (2), the $i^{\text {th }}$ farmer will choose the modern if $\varepsilon_{i}>-X_{i} \beta$. The probability that $Y_{i}$ equals one (i.e. that the farmer adopts the modern greenhouse) is a function of the independent variables:

$$
P_{i}=\operatorname{Pr}\left(Y_{i}=1\right)=\operatorname{Pr}\left(Y_{i}^{*}>0\right)=\operatorname{Pr}\left(X_{i} \beta+\varepsilon_{i}>0\right)=\operatorname{Pr}\left(\varepsilon_{i}>-X_{i} \beta\right)=F\left(X_{i} \beta\right)
$$


where $\operatorname{Pr}($.$) is a probability function, and F\left(X_{i} \beta\right)$ is the cumulative distribution function for $\varepsilon_{i}$ evaluated at $X_{i} \beta$. The probability that a farmer will adopt the modern greenhouse is a function of the vector of explanatory variables, the vector of unknown parameters and the unobserved error term. If $\varepsilon_{i}$ is normal, $F$ will have a cumulative normal distribution (Ralm \& Huffman, 1984), and the functional form of $F$ is specified with a probit model, where $\varepsilon_{i}$ is an independently, normally distributed error term with zero mean and constant variance $\sigma^{2}$.

\subsubsection{Irrigation system and seedling adoption}

There are more than two alternatives associated with irrigation system and seedling adoptions. Farmers may choose among three irrigation systems (i.e. sprinkler $=1$, spraying $=2$, drip $=3$ ) and three seedling sources (i.e. self-produced $=1$, domestic seedling $=2$, imported seedling $=3$ ). The ordinal nature of the dependent variable motivates the use of an ordered probit model (Daykin \& Moffatt, 2002; Greene, 2008).

For irrigation, a farmer will choose to adopt a spraying system if the utility gained from adopting it is greater than the utility of adopting a sprinkler system, and the farmer will choose to adopt a drip system if the utility gained from adopting it is greater than the utility of adopting a sprinkler system. In a same manner, a farmer will choose to use domestic seedlings if the utility gained from using it is greater than the utility of using self-produced seedlings, and the farmer will choose to use imported seedlings if the utility gained from using it is greater than the utility of using domestic seedlings.

The ordered probit model is commonly presented as a latent-variable model. Defining $Y_{i}^{*}=X_{i} \beta+\varepsilon_{i}$ as a latent variable ranging from $-\infty$ to $+\infty$, this variable indicates a farmer's preference for adopting a better technology associated with either irrigation systems or seedlings. Higher $Y^{*}$ indicates a stronger preference for adopting a better technology. The utility level for each individual farmer $U_{\mathrm{ji}}$ (or latent variable $Y_{i}^{*}$ ) is not observable, but we observe that:

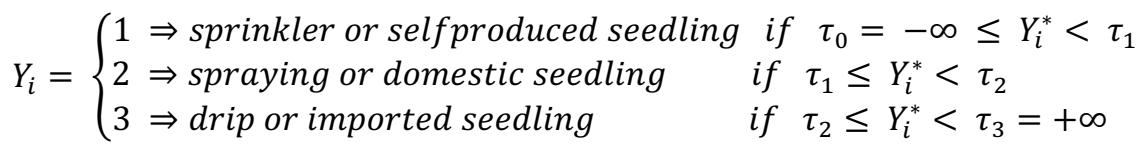

where $0<\tau_{1}<\tau_{2}$ are unknown threshold parameters to be estimated with $\beta$. Assuming that $u_{\mathrm{i}}$ follows a normal distribution, we obtain the following probabilities:

$$
\begin{aligned}
\operatorname{Pr}(Y=1 \mid X) & =\operatorname{Pr}\left(Y_{i}^{*}<\tau_{1} \mid X\right) \\
& =\operatorname{Pr}\left(X_{i} \beta+u_{i}<\tau_{1} \mid X\right)=F\left(\tau_{1}-X_{i} \beta\right) \\
\operatorname{Pr}(Y=2 \mid X) & =\operatorname{Pr}\left(\tau_{1} \leq Y_{i}^{*}<\tau_{2} \mid X\right) \\
& =\operatorname{Pr}\left(\tau_{1} \leq X_{i} \beta+u_{i}<\tau_{2} \mid X\right)=F\left(\tau_{2}-X_{i} \beta\right)-F\left(\tau_{1}-X_{i} \beta\right) \\
\operatorname{Pr}(Y=3 \mid X) & =\operatorname{Pr}\left(\tau_{2} \leq Y_{i}^{*}<\tau_{3} \mid X\right) \\
& =\operatorname{Pr}\left(\tau_{2} \leq X_{i} \beta+u_{i}<\tau_{3} \mid X\right)=F\left(\tau_{3}-X_{i} \beta\right)-F\left(\tau_{2}-X_{i} \beta\right) \\
& =1-F\left(\tau_{2}-X_{i} \beta\right)
\end{aligned}
$$


where $X$ is the $n \times k$ matrix of the explanatory variables, and $\beta$ is a $k \times 1$ vector of parameters to be estimated, $\operatorname{Pr}(\cdot)$ is a probability function, $\tau_{1}, \tau_{2}$, and $\tau_{3}$ are the cut-points and $F(\cdot)$ is the cumulative distribution function for $u_{\mathrm{i}}$.

The examined factors compose of four specific groups: 1) Producer demographic characteristics proxied by variables as main labor gender, age, education level and farming experience, 2) Economic factors representative by household income and farm size, 3) Farmers' perception on technology characteristics and performance as learning time, assessment of potential yield increase, information accessibility and market demand, and 4) Farmers' perception on natural conditions as water supply and climate.

\subsubsection{Conditional mixed process models (CMP)}

The adoption of a specific technology may correlate to other technologies. For example, an investment in better greenhouse frames can lead to adopt an advanced irrigation system. Adoption of new flower species that are sensitive to virus disease may require the application of drip irrigation system. Therefore, instead of using separate regression models, the study simultaneously runs a system of equations that assume error terms are correlated across equations, using Conditional Mixed-Process (CMP) models with cmp command in Stata 14.

The conditional mixed-process framework implemented by David Roodman's CMP command. The underlying concept of modeling in the CMP framework is that one may often want to jointly estimate two or more equations with linkages among their error processes. The concept is similar to the concept of Zellner's Seemingly Unrelated Regression estimator. However, the CMP modeling framework is essentially that of seemingly unrelated regressions, but in a much broader sense. The individual equations need not be classical regressions with a continuous dependent variable. They may be binary, estimated by binomial probit; ordered, estimated by ordered probit; categorical, estimated by multinomial probit; censored, estimated by tobit; or based on interval measures, estimated by intreg (Baum, 2016). The CMP command can be expressed as a system of equations as followed:

$$
\begin{aligned}
& y_{1 i}=a+b S_{i}+c X_{i}+e_{1 i} \\
& y_{2 i}=a+b S_{i}+c X_{i}+e_{2 i} \\
& y_{3 i}=a+b S_{i}+c X_{i}+e_{3 i}
\end{aligned}
$$

where $y_{1}, y_{2}, y_{3}$ are dependent variables associated with three different technologies; $S$ is the vector of farmer's characteristics and $X$ is the vector of technology characteristics, and $e_{\mathrm{s}}$ are the error terms, where $\operatorname{cov}[e 1, e 2, e 3] \neq 0$ (i.e. $e_{1}, e_{2}$, and $e_{3}$ could pair wise correlate.)

\subsection{Data and sampling methods}

Primary data were collected by direct interview. Sample size was calculated by the Cochran's formula. Given $p$ of 0.626 (percentage of flower cultivated area applying advanced agricultural technology was $62.6 \%$, by statistical figures of province Lam Dong in 
2012); $q$ of 0.374 ; estimated error of $8 \%$; and a probability of $95 \%$, calculated sample size is approximately 140 . Surveyed sample size comprises 228 observations including 126 cases in Ho Chi Minh City and 104 cases in Lam Dong province. Observations in Ho Chi Minh City were selected using a proportionate stratified sampling method thanks to the availability of the sample frame of 716 orchid producers. Meanwhile, quota and convenient sampling was applied to select 104 flower producers located in Lam Dong province because sample frame could not be collected. A questionnaire includes demographic details, socioeconomic and technology was printed out and giving to all the households to fill out. To avoid misunderstanding, the content of each question was explained carefully by interviewers.

The definition of dependent and independent variables is showed in Table 1.

\section{Table 1.}

Definition of variables in empirical models.

\begin{tabular}{|c|c|}
\hline greenhouse & $\begin{array}{l}\text { Type of a greenhouse, measured as a binary variable: } 0 \text { if simple greenhouse, } 1 \\
\text { if modern one. }\end{array}$ \\
\hline irriscore & $\begin{array}{l}\text { Type of irrigation system, measured as ordinal variable: } 1 \text { if sprinkler, } \\
2 \text { if spraying, and } 3 \text { if drip system application. }\end{array}$ \\
\hline seedscore & $\begin{array}{l}\text { Type of seedling, measured as an ordinal variable: } 1 \text { if self-produced, } \\
2 \text { if domestic seedling, and } 3 \text { if import seedling. }\end{array}$ \\
\hline
\end{tabular}

Independent variables

laborsex Gender of main labor, measured as a binary variable: 1 if male, 0 if female

laboredu Enrollment years of main labor, measured in years.

agriexper Working year in agriculture of main labor, measured in years.

ln_income Logarithm of estimated annual household income per hectare, measured in millions VND.

ln_area Logarithm of total agricultural area of household, measured in hectares.

orchid_ratio The ratio of orchid cultivated over total agricultural area.

coopmember Cooperative membership, measured as a binary variable: 1 if yes, 0 if no.

vertilink Working in vertical linkage, measured as a binary variable: 1 if yes, 0 if no.

oralcontrac Product sale via informal contract, measured as binary variable: 1 if yes, 0 if no.

indirexport $\quad$ Product sale to export companies, measured as binary variable: 1 if yes, 0 if no.

learntimemo Learning time before technology adoption, measured in months. 


\begin{tabular}{|c|c|}
\hline farlearn & $\begin{array}{l}\text { Technology learning from faraway farmers, measured as binary variable: } \\
1 \text { if yes, } 0 \text { if no. }\end{array}$ \\
\hline trial & $\begin{array}{l}\text { Technology learning from doing trial, measured as a binary variable: } \\
1 \text { if yes, } 0 \text { if no. }\end{array}$ \\
\hline trained & Technology learnt from training, measured as a binary variable: 1 if yes, 0 if no. \\
\hline extension & $\begin{array}{l}\text { Technology information from agricultural extension service, measured as a } \\
\text { binary variable: } 1 \text { if yes, } 0 \text { if no. }\end{array}$ \\
\hline association & $\begin{array}{l}\text { Technology information from agricultural association, measured as a binary } \\
\text { variable: } 1 \text { if yes, } 0 \text { if no. }\end{array}$ \\
\hline beneflev1 & $\begin{array}{l}\text { Producer's perception of benefit level got from agricultural extension service } \\
\text { information, measured as scores from } 1 \text { (lowest) to } 10 \text { (highest). }\end{array}$ \\
\hline beneflev2 & $\begin{array}{l}\text { Producer's perception of benefit level got from other agricultural R\&D } \\
\text { organizations information, measured as scores from } 1 \text { (lowest) to } 10 \text { (highest). }\end{array}$ \\
\hline beneflev3 & $\begin{array}{l}\text { Producer's perception of benefit level got from company information, } \\
\text { measured as scores from } 1 \text { (lowest) to } 10 \text { (highest). }\end{array}$ \\
\hline markgradinfo & $\begin{array}{l}\text { Producer's perception of difficulty of market technical standard, measured as } \\
\text { scores from } 1 \text { (most difficult) to } 10 \text { (easiest). }\end{array}$ \\
\hline self-efficacy & $\begin{array}{l}\text { Composite variable representative for producer's perceived ability to adopt } \\
\text { modern technology (price, replace cost, difficulty in learning, and suitability of } \\
\text { technology to farm condition) created by factor analysis. }\end{array}$ \\
\hline watersupply & $\begin{array}{l}\text { Producer's perception of water supply capacity, measured as scores from } 1 \\
\text { (worst) to } 10 \text { (best). }\end{array}$ \\
\hline climate & $\begin{array}{l}\text { Producer's perception of climate suitability measured as scores from } 1 \text { (worst) } \\
\text { to } 10 \text { (best). }\end{array}$ \\
\hline location & Location, measured as a binary variable: 1 if Lam Dong, 0 if Ho Chi Minh City. \\
\hline
\end{tabular}

The status of floriculture in two locations is presented using descriptive statistics. A set of binary and ordered probit models are applied with CMP command to examine the determinants of technology adoption. Stata 14 is used for data analysis.

\section{Results and Discussion}

\subsection{Technology adoption of flower producers}

This section presents a description of some main indicators related to technology adoption of flower producers in both Lam Dong province and Ho Chi Minh City as shown in Table 2.

The rate of using modern greenhouses is $37.7 \%$ for both locations. Modern greenhouse adopter is only $2 \%$ in Ho Chi Minh City while in Lam Dong it is over $82 \%$. The distinction 
is that tropical orchid prefers high temperature, humidity, strong sunlight and an airy environment. Therefore, simple greenhouse roofed by sunshade net sheets is typical for orchid cultivation while modern greenhouse is suitable for environment-sensitive flower species grown in Lam Dong province.

Regarding irrigation systems, flower producers mainly use mist spraying systems $(65.8 \%)$ in both locations. This system is not too complicated and costly to apply and saves labor and time. While sprinkler system is still popular in Ho Chi Minh City (42\%) it is rarely used in Lam Dong for flower production (only 1\%). Drip irrigation adopters mostly locate in Lam Dong and account for only $10.5 \%$ of all observation. In general, it is likely that Lam Dong producers adopt more modern irrigation technology than that in Ho Chi Minh City.

The proportion in use of domestic produced seedlings is over $50 \%$ and shares of imported and self-propagating seedling adopters are equal at approximately 20-25\%. However, orchid producers in Ho Chi Minh City mostly use self-propagating and domesticproduced seedlings ( $42.86 \%$ and $4.76 \%$ respectively). In contrast, self-propagating seedlings account for an extremely low proportion compared to domestic-produced and imported seedlings in Lam Dong (1.96\%, 52.94\% and 45.10\% respectively).

\section{Table 2.}

Technology adoption in surveyed households.

\begin{tabular}{llcc}
\hline Dependent variables & Type & Frequency & Per cent \\
\hline Greenhouse type & simple & 142 & 62.3 \\
& modern & 86 & 37.7 \\
\hline Irrigation system & sprinkler & 54 & 23.7 \\
& mist spraying & 150 & 65.8 \\
& drip irrigation & 24 & 10.5 \\
\hline Seedling type & self-propagating & 56 & 24.6 \\
& domestic produced & 120 & 52.6 \\
& import & 52 & 22.8 \\
\hline
\end{tabular}

\subsection{Characteristics of flower producer}

The demographic characteristics of flower producers in Ho Chi Minh City and Lam Dong province are relatively similar. Male labor mainly occupied in flower production (80\% in Ho Chi Minh City, 75\% in Lam Dong and 78\% in both locations). Producers are at 50-year-old and get a high school education level, on average. The farming experience of flower producer is impressive with nearly 20 years at Lam Dong, 18 years in Ho Chi Minh City and 18 years on average. Farm size is at 0.51 hectare on average with large variation. Similar is annual agricultural income which is relatively high (around 370 million VND/year, corresponding to 16 thousand \$US) with huge variation. The figures also indicate a high 
income of flower production compared to ordinary food crops. Flower is cultivated in $75 \%$ of the total farm cultivated land area (Table 3).

Seeking information about technology and learning prior to adoption are very important for flower producers. Producers often look for information from different sources, such as the internet, observing the practices of other producers and other sources. Learning from agriculture extension staff, associations and supply companies is observed. Producers also take part in training courses organized by public and/or private service organizations to learn. Through these activities, they can accumulate knowledge and experience before adopting new technology. Within these information sources, learning from other producers is dominant (Table 4). The average learning time of producer is about one year (Table 3). It is long enough for them to acquire the basic knowledge to adopt new technology. Producers often give high evaluation for benefit they get from extension service in compared to other R\&D organizations and technology supply companies (Table 3).

In both locations, few farms joint cooperatives or vertical linkage in production and commercialization. Less than $20 \%$ of surveyed farms have cooperative membership and/or connect to the flower value chain. Therefore, most of them must sell to a local dealer while fewer cases directly connect to wholesale or retail markets. Because of that, the percentage of using the official contract is low (Table 4).

\section{Table 3.}

Producers' demographical, economic features and technology learning process

\begin{tabular}{lccccc}
\hline Variables & Obs & Mean & Std. Dev & Min & Max \\
\hline Education level (year) & 221 & 10.3 & 3.9 & 2 & 20 \\
Farming experience (year) & 226 & 18.2 & 11.7 & 1 & 53 \\
Main labor age (year) & 227 & 49.6 & 11.3 & 21 & 84 \\
Agricultural income (Mil. VND/year) & 227 & 370.7 & 458.7 & 5 & 6,000 \\
Cultivated area (1,000 m²) & 228 & 5.1 & 5.9 & 0.1 & 50 \\
Flower area ratio & 228 & 0.75 & 0.32 & 0.02 & 1 \\
Learning time for technology (month) & 222 & 12.7 & 13.7 & 0 & 120 \\
Information source of technology (source) & 228 & 3.1 & 1.8 & 0 & 7 \\
Benefit from extension service (score) & 228 & 6.6 & 2.4 & 1 & 10 \\
Benefit from other R\&D organizations (score) & 227 & 4.9 & 2.7 & 1 & 10 \\
Benefit from technology supply companies & 225 & 4.6 & 2.8 & 1 & 10 \\
(score) & & & & & \\
\hline
\end{tabular}




\section{Table 4.}

Technology learning, information source and market channel.

\begin{tabular}{lcc}
\hline Option from the questionaire & Frequency & Percent \\
\hline Technology learnt before application & 227 & 100.0 \\
Learn from neighboring farms & 208 & 92.0 \\
Learn from faraway farms & 143 & 63.3 \\
Learn from training course & 123 & 54.4 \\
Trial before application & 103 & 45.6 \\
Internet & 86 & 37.9 \\
Other growers & 205 & 90.3 \\
Agricultural extension staff & 124 & 54.6 \\
Association/Unions & 86 & 37.8 \\
Training course & 127 & 55.9 \\
Supply companies & 41 & 18.1 \\
Other sources & 35 & 15.4 \\
Cooperative membership & 28 & 12.7 \\
Joint vertical linkage & 43 & 19.8 \\
Sale to dealer & 167 & 73.6 \\
Sale to wholesaler & 65 & 28.6 \\
Sale to retailer & 31 & 24.6 \\
Sale with oral contract & 5.9 \\
Sale with official contract & 52 \\
Sale to indirect exporter & 21 & 2.2 \\
\hline & & 43 \\
\hline
\end{tabular}

Flower producers are likely interested in technology characteristics and benefits they may get from technology adoption and market conditions for new products. Measuring producer's perception is applied to reflect their behavior to risk of technology adoption. Survey results show that flower producers are very optimistic in evaluating different technology features, except in technology guidance from suppliers. They also believe success in adopting technology, in terms of yield increase, quality improvement and profit increase. Their perception of market availability, market capacity and market standard is highly positive, and at a moderate level for price and technical standard information. Flower producers also positively evaluate water supply and weather conditions for flower cultivation. The average scores of 8.0 and 9.0 over 10 point mean a high evaluation on natural 
conditions in both Lam Dong province and Ho Chi Minh City for floriculture (Table 5).

\section{Table 5.}

Farm's perception on technology adoption and market for new products.

\begin{tabular}{|c|c|c|c|c|c|}
\hline Variables & Obs & Mean & Std.Dev & Min & Max \\
\hline Technology availability & 228 & 8.7 & 1.6 & 2 & 10 \\
\hline Technology price & 227 & 7.0 & 1.9 & 1 & 10 \\
\hline Spare part availability & 228 & 8.4 & 1.9 & 1 & 10 \\
\hline Cost of spare part & 227 & 7.1 & 1.9 & 1 & 10 \\
\hline Difficulty in learning technology & 227 & 7.9 & 1.9 & 1 & 10 \\
\hline Technology adaptivity to farm & 228 & 8.3 & 1.8 & 1 & 10 \\
\hline Technology suitability to farm & 228 & 8.4 & 1.6 & 1 & 10 \\
\hline Technology guidance from suppliers & 222 & 4.8 & 3.1 & 1 & 10 \\
\hline Yield increased as technology adopted & 225 & 7.2 & 2.0 & 1 & 10 \\
\hline Product quality improved as tech. adopted & 225 & 7.1 & 2.1 & 1 & 10 \\
\hline Profit increased as technology adoption & 220 & 7.0 & 2.1 & 1 & 10 \\
\hline Market availability for product & 227 & 8.0 & 1.7 & 3 & 10 \\
\hline Market capacity for product & 226 & 7.7 & 1.7 & 2 & 10 \\
\hline Market standard for product & 226 & 7.4 & 1.6 & 1 & 10 \\
\hline Market price information & 227 & 6.5 & 2.4 & 1 & 10 \\
\hline Market technical standard information & 228 & 6.8 & 2.2 & 1 & 10 \\
\hline Water supply & 226 & 9.0 & 1.4 & 5 & 10 \\
\hline Climate & 226 & 8.0 & 1.8 & 3 & 10 \\
\hline
\end{tabular}

\subsection{Determinants of Agricultural Technological Adoption}

Table 6 presents the estimations of determinants of agricultural technology adoption in floriculture by applying conditional mixed-process probit models. Unrestricted (model 1) and restricted models (model 2) are run to compare changes in regression coefficients. Both models are valid if the probabilities of Chi-squared equal zero.

First, conditional mixed-process models revealed that greenhouse adoption is uncorrelated to irrigation system and seedling type (atanhrho_12 and atanhrho_13 are not statistically significant at a level of 0.05 ), while irrigation system adoption slightly correlates to seedling type (at a level of 0.10). It is possibly that investment in a more modern irrigation system requires the use of new flower species and a high-quality seedling source to realize 
the expectations of financial returns. In addition, drip irrigation is a technical solution to prevent soil-borne diseases and is often applied for the production of valuable flower species.

Second, there are numerous determinants of technology adoption in the use of greenhouse technology, irrigation systems and seedlings. In general, technology adoption is affected by the producer's demographic characteristics (proxied by variables such as main labor gender, age, age squared, education level and farming experience); economic factors (farm size, household income and ratio of land for flower cultivation); market accessibility (exported orientation and informal contract business); learning issues and information source (learning time, ways of learning and information source); and the producer's perception of technology characteristics, information accessibility and market demand.

The gender and age of the household's main labor influence the shift from a simple to a modern greenhouse. Males have a stronger effect on the shift than females, as they tend to be more risk tolerant when making decisions. However, it is likely that the greenhouse technology adopters require more experience when the relation between age and probability of adoption has the shape of a concave curve. This means that passing an age threshold, the older prefer adopting modern greenhouse technology.

A similar impact of farm income on greenhouse adoption is observed. It is possible that the application of modern greenhouse technology requires a greater cash investment. Therefore, producers need to accumulate capital to an essential threshold that corresponds to investment costs. Producers with larger farms and greater specialization in floriculture adopt more modern greenhouse technology.

Market channels also influence greenhouse adoption. An export-oriented farm business enhances the probability of modern greenhouse adoption, while an informal business contract at a local market would reduce it. Learning time and technology information from the internet and supply companies have positive effects on the probability of using modern greenhouse technology.

For irrigation system adoption, education, farm size and more specialization in floriculture have positive impacts on the probability of shifting from a sprinkler system to mist spray and drip irrigation. The adoption of a modern irrigation system requires farms to have close vertical linkage, better perceptions on the market standards of products and water supply. These findings are reasonable, as adopters of better irrigation systems need better market access, a clean water source and careful maintenance. Producers must seek technology information, evaluate different factors such as price, replacement cost, difficulty in learning, and suitability of technology to farm conditions before making a decision. As a result, self-efficacy positively influences the probability of adopting a better irrigation system. Irrigation adoption is positively affected by technology information from flower associations and training. It seems that information from agricultural extension is not useful in the application of irrigation systems for farms. 


\section{Table 6.}

Estimations of determinants of technology adoption.

\begin{tabular}{|c|c|c|c|c|c|c|}
\hline \multirow[t]{2}{*}{ Variables } & \multicolumn{3}{|c|}{ Model 1} & \multicolumn{3}{|c|}{ Model 2} \\
\hline & Coef. & Std.Err. & Prob. & Coef. & Std.Err. & Prob. \\
\hline \multicolumn{7}{|l|}{ Greenhouse application } \\
\hline Location (Lam Dong = 1) & 15.92 & 4.63 & 0.001 & 10.11 & 2.49 & 0 \\
\hline Gender of household head & 2.38 & 1.06 & 0.025 & 0.933 & 0.421 & 0.027 \\
\hline Age of household head & -0.973 & 0.313 & 0.002 & -0.401 & 0.147 & 0.006 \\
\hline $\begin{array}{l}\text { Square of Age of household } \\
\text { head }\end{array}$ & 0.011 & 0.003 & 0.001 & 0.005 & 0.002 & 0.006 \\
\hline Education (highest degree) & 0.006 & 0.236 & 0.98 & & & \\
\hline Agricultural experience & 0.163 & 0.09 & 0.071 & & & \\
\hline $\begin{array}{l}\text { Square of Agricultural } \\
\text { experience }\end{array}$ & -0.005 & 0.002 & 0.035 & & & \\
\hline Ln(total land area) & 1.84 & 1.05 & 0.078 & 1.12 & 0.393 & 0.004 \\
\hline Land ratio for flower & 4.84 & 2.32 & 0.037 & 2.2 & 0.777 & 0.005 \\
\hline Ln(household income) & -9.84 & 7.75 & 0.204 & -5.95 & 1.84 & 0.001 \\
\hline Square of Ln(household income) & 1.03 & 0.87 & 0.236 & 0.671 & 0.224 & 0.003 \\
\hline Cooperative member & 1.45 & 0.974 & 0.136 & & & \\
\hline Vertical linkage & 0.446 & 0.82 & 0.587 & & & \\
\hline Export oriented & 8.65 & 2.72 & 0.001 & 2.83 & 0.891 & 0.002 \\
\hline Informal business contract & -1.44 & 0.896 & 0.109 & -1.24 & 0.489 & 0.011 \\
\hline Market standard & 2.54 & 1.08 & 0.018 & & & \\
\hline Market technical standard & -0.169 & 0.143 & 0.237 & & & \\
\hline Self-efficacy & -0.624 & 0.417 & 0.135 & & & \\
\hline Benefit from company & -0.113 & 0.117 & 0.335 & & & \\
\hline Time to learn technology & 0.087 & 0.042 & 0.038 & 0.041 & 0.017 & 0.015 \\
\hline Information from internet & 2.33 & 1.07 & 0.029 & 1.08 & 0.42 & 0.01 \\
\hline Information from company & 6.58 & 1.71 & 0 & 2.57 & 0.478 & 0 \\
\hline Learn from faraway farms & 0.429 & 0.681 & 0.529 & 1.13 & 0.618 & 0.068 \\
\hline Trial before application & -2.87 & 0.675 & 0 & -0.924 & 0.551 & 0.094 \\
\hline Agricultural extension & 0.585 & 0.657 & 0.374 & & & \\
\hline
\end{tabular}




\begin{tabular}{|c|c|c|c|c|c|c|}
\hline \multirow[t]{2}{*}{ Variables } & \multicolumn{3}{|c|}{ Model 1} & \multicolumn{3}{|c|}{ Model 2} \\
\hline & Coef. & Std.Err. & Prob. & Coef. & Std.Err. & Prob. \\
\hline Flower association & -2.17 & 1.06 & 0.04 & & & \\
\hline Training & -2.26 & 0.883 & 0.011 & & & \\
\hline Water supply & -0.402 & 0.172 & 0.019 & -0.388 & 0.118 & 0.001 \\
\hline Intercept & 20.68 & 15.5 & 0.182 & 11.07 & 3.89 & 0.004 \\
\hline \multicolumn{7}{|l|}{ Irrigation application } \\
\hline Location $($ Lam Dong = 1) & 3.03 & 0.806 & 0 & 1.89 & 0.414 & 0 \\
\hline Age of household head & -0.106 & 0.059 & 0.076 & & & \\
\hline $\begin{array}{l}\text { Square of Age of household } \\
\text { head }\end{array}$ & 0.0012 & 0.0006 & 0.042 & & & \\
\hline Education (highest degree) & 0.234 & 0.08 & 0.004 & 0.125 & 0.061 & 0.04 \\
\hline Agricultural experience & -0.009 & 0.039 & 0.827 & & & \\
\hline $\begin{array}{l}\text { Square of Agricultural } \\
\text { experience }\end{array}$ & 0.0005 & 0.0008 & 0.543 & & & \\
\hline Ln(total land area) & 0.61 & 0.202 & 0.002 & 0.448 & 0.115 & 0 \\
\hline Land ratio for flower & 1.15 & 0.406 & 0.005 & 0.679 & 0.339 & 0.045 \\
\hline Ln(household income) & -0.811 & 0.923 & 0.379 & & & \\
\hline Square of Ln(household income) & 0.09 & 0.1 & 0.369 & & & \\
\hline Cooperative member & 0.061 & 0.338 & 0.857 & & & \\
\hline Vertical linkage & 0.906 & 0.381 & 0.017 & 0.741 & 0.251 & 0.003 \\
\hline Export oriented & 1.01 & 0.726 & 0.164 & & & \\
\hline Market standard & 0.5 & 0.304 & 0.1 & 0.49 & 0.247 & 0.047 \\
\hline Informal business contract & 0.379 & 0.239 & 0.113 & & & \\
\hline Market technical standard & 0.058 & 0.06 & 0.337 & & & \\
\hline Self-efficacy & 0.262 & 0.145 & 0.071 & 0.296 & 0.108 & 0.006 \\
\hline Benefit from company & 0.062 & 0.046 & 0.185 & & & \\
\hline Time to learn technology & -0.016 & 0.009 & 0.09 & & & \\
\hline Learn from faraway farms & 0.017 & 0.31 & 0.957 & & & \\
\hline Trial before application & -0.293 & 0.314 & 0.35 & & & \\
\hline Agricultural extension & -1.23 & 0.314 & 0.004 & -0.703 & 0.273 & 0.01 \\
\hline Flower association & 1.07 & 0.362 & 0.003 & 0.767 & 0.276 & 0.005 \\
\hline
\end{tabular}




\begin{tabular}{|c|c|c|c|c|c|c|}
\hline \multirow[t]{2}{*}{ Variables } & \multicolumn{3}{|c|}{ Model 1} & \multicolumn{3}{|c|}{ Model 2} \\
\hline & Coef. & Std.Err. & Prob. & Coef. & Std.Err. & Prob. \\
\hline Training & 0.647 & 0.358 & 0.071 & 0.512 & 0.269 & 0.057 \\
\hline Water supply & 0.271 & 0.106 & 0.011 & & & \\
\hline Intercept 1 & 1.68 & 2.49 & 0.5 & 1.69 & 0.508 & 0.001 \\
\hline Intercept 2 & 6.68 & 2.46 & 0.007 & 5.15 & 0.78 & 0 \\
\hline \multicolumn{7}{|l|}{ Seedling application } \\
\hline Location $($ Lam Dong $=1)$ & 2.89 & 0.527 & 0 & 2.66 & 0.375 & 0 \\
\hline Education (highest degree) & 0.17 & 0.076 & 0.025 & 0.173 & 0.064 & 0.007 \\
\hline Age of household head & -0.196 & 0.072 & 0.007 & -0.142 & 0.062 & 0.022 \\
\hline Square of Age of household head & 0.002 & 0.0007 & 0.01 & 0.001 & 0.0006 & 0.03 \\
\hline Agricultural experience & 0.168 & 0.047 & 0 & 0.153 & 0.039 & 0 \\
\hline $\begin{array}{l}\text { Square of Agricultural } \\
\text { experience }\end{array}$ & -0.003 & 0.001 & 0.002 & -0.003 & 0.0008 & 0.001 \\
\hline Ln(total land area) & 0.216 & 0.178 & 0.226 & & & \\
\hline Land ratio for flower & 0.038 & 0.402 & 0.924 & & & \\
\hline Ln(household income) & -1.27 & 0.733 & 0.082 & & & \\
\hline Square of Ln(household income) & 0.144 & 0.077 & 0.06 & & & \\
\hline Cooperative member & 0.869 & 0.333 & 0.009 & 0.603 & 0.299 & 0.044 \\
\hline Vertical linkage & -0.331 & 0.284 & 0.243 & & & \\
\hline Export oriented & 0.292 & 0.483 & 0.6 & & & \\
\hline Market standard & -0.658 & 0.28 & 0.019 & -0.553 & 0.24 & 0.021 \\
\hline Informal business contract & -0.067 & 0.214 & 0.755 & & & \\
\hline Market technical standard & 0.167 & 0.057 & 0.004 & 0.155 & 0.045 & 0 \\
\hline Self-efficacy & 0.05 & 0.121 & 0.677 & & & \\
\hline Benefit from company & 0.088 & 0.044 & 0.044 & 0.085 & 0.039 & 0.031 \\
\hline Learn from faraway farms & 0.306 & 0.279 & 0.273 & & & \\
\hline Time to learn technology & 0.017 & 0.009 & 0.068 & 0.019 & 0.008 & 0.014 \\
\hline Trial before application & -0.07 & 0.272 & 0.796 & & & \\
\hline Agricultural extension & -0.542 & 0.354 & 0.126 & & & \\
\hline Flower association & 0.688 & 0.361 & 0.057 & 0.587 & 0.259 & 0.023 \\
\hline
\end{tabular}




\begin{tabular}{lcccccc}
\hline Variables & \multicolumn{5}{c}{ Model 1 } & \multicolumn{3}{c}{ Model 2 } \\
\cline { 2 - 7 } & Coef. & Std.Err. & Prob. & Coef. & Std.Err. & Prob. \\
\hline Training & 0.115 & 0.357 & 0.748 & & & \\
Water supply & 0.104 & 0.079 & 0.192 & & & \\
intercept 1 & -2.63 & 2.43 & 0.28 & -0.027 & 1.49 & 0.985 \\
intercept 2 & 0.264 & 2.4 & 0.913 & 2.67 & 1.76 & 0.079 \\
\hline atanhrho_12 & 0.109 & 1.08 & 0.919 & -0.148 & 0.332 & 0.655 \\
atanhrho_13 & 1.08 & 1.28 & 0.4 & 0.394 & 0.297 & 0.185 \\
atanhrho_23 & 0.329 & 0.192 & 0.086 & 0.385 & 0.152 & 0.011 \\
\hline rho_12 & 0.109 & 1.07 & & -0.147 & 0.325 & \\
rho_13 & 0.793 & 0.476 & & 0.374 & 0.255 & \\
rho_23 & 0.318 & 0.192 & & 0.367 & 0.131 & \\
\hline Log Pseudo Likelihood & -216.64 & & & -258.65 & & \\
Wald Chi2 & 572.78 & & & 260.61 & & \\
Number of Obs & 198 & & & 218 & & \\
\hline
\end{tabular}

Producers must grow new flower varieties or species to respond to changes in consumers' preferences. When obsolete varieties become less profitable, producers must buy newly released varieties or species that are only provided by domestic and/or importing companies. Botanical degradation and disease infection are other problems occurring when self-propagating seedlings are overused over time. Seeding companies can provide virus-free and seed-borne disease-free seedlings thanks to in-vitro production. As regards seedling use, better education and maturity in age tend to encourage the shift from using self-propagating seeds to an external source. However, upgrading to a new seedling source might present a risk to flower producers. They need more knowledge and experience to reduce the risks of technology adoption. Therefore, experience, learning time, information from flower associations, perceptions on the benefits from company information, perceptions on market standards and market technical standards for new products are positive determinants of using seedlings supplied by domestic companies and/or imported as these factors reduce the risks of using new technology.

Positive regression coefficients of location throughout all CMP probit models indicated that the probability of technology adoption by the flower producers in Lam Dong province is higher than by those in Ho Chi Minh City. Obviously, flower farms in Lam Dong are more highly specialized and have more experience in floriculture. In addition, while flower production is the main source of income for producers in Lam Dong, it contributes an extra income source to farmers in Ho Chi Minh City. 
In general, the results in most of the cases are similar, as expected, and consistent with previous empirical studies. The main determinants of technology adoption are the gender, education and farming experience of producers. Economic determinants are farm size and the financial capacity of producers. Knowledge and experience of learning processes before adoption are important for flower producers, as these factors help to reduce the risks of technology application. Better technology and market information accessibility has a considerable impact on technology adoption in floriculture.

\section{Conclusion and Policy Implications}

The study aims to identify specific determinants that affect producer behavior to adopt advanced agricultural technology in the flower production sector in Lam Dong province and Ho Chi Minh City. Primary data were collected from 228 flower producers. Conditional mixed-process probit models were applied to examine the impact of potential determinants.

The results indicate that there are several factors influencing technology adoption in floriculture. The main demographic characteristics are the gender, education and farming experience of producers. Economic factors are farm size and the financial capacity of producers. Knowledge and experience of learning processes before adoption also play an important role. Better technology and market information accessibility positively enhances the probability of modern technology adoption. The probability of technology adoption by flower producers in Lam Dong province are always higher than by those in Ho Chi Minh City, since flower production is the main economic activity in that region.

At present, there is a strong shift from traditional to advanced technology in agriculture, and more specifically in the floriculture sector, especially in Lam Dong province and Ho Chi Minh City. Although small-scale production is still a significant problem for the floriculture sector in Vietnam, the adoption of new technology would help farms to enhance productivity and profitability. The study results suggest some potential solutions to improve the sector. The enhancement of educational level of flower producers will have a positive effect in the long term. Public and private service providers in agriculture can effectively contribute to technology adoption by providing technical training, on-site demonstrations, experience exchanges and the introduction of new technology. In other words, better provision of technology information by both public and private service providers will promote technology adoption. Lastly, better policies for land accumulation and a free land market would help to increase farm size, stimulating the technology adoption rate in floriculture.

Further studies in this field of research should focus on producers' behavior, especially on how farmers behave in terms of the risks of their decisions on technology adoption. Other factors such as market standards, market capacity, and price fluctuations in the market need to be considered as well, as these are the limitations of the present study. 


\section{Acknowledgement}

This work was supported by the Ministry of Education and Training under grant for the study code B2017-KSA-14. The authors appreciate helps of Mr. Phung Thanh Binh, Lecturer of School of Economics, University of Economics Ho Chi Minh City for econometric technique support

\section{References}

Adesina, A., \& Zinnah, M. (1993). Technology characteristics, farmers' perceptions and adoption decisions: A tobit model application in Sierra Leone. Agricultural Economics, 9(4), 297-311.

Affholder, F., Jourdain, D., Quang, D. D., Tuong, T. P., Morize, M., \& Ricome, A. (2010). Constraints to farmers' adoption of direct-seeding mulch-based cropping systems: a farm scale modeling approach applied to the mountainous slopes of Vietnam. Agricultural Systems, 103(1), 51-62.

Baffoe-Asare, R., Danquah, J., \& Annor-Frempong, F. (2013). Socioeconomic factors influencing adoption of COPADEC and cocoa high-tech technologies among smallholder farmers in Central Region of Ghana. American Journal of Experimental Agriculture, 3(2), 277-292.

Baum, F. C. (2016). Conditional Mixed-Process Models. United States: Boston College. Retrieved from http://fmwww.bc.edu/ECC/S2016/8823/ECON8823.S2016.nn14.slides.pdf.

Cheteni, P., Mushunje, A., \& Taruvinga, A. (2014). Barriers and incentives to potential adoiption of biofuels crops by smallholder farmers in the Eastern Cape province, South Africa. Journal Environmental Economics, 5(3), 71-77.

CIMMYT Economics Program. (1993). The Adoption of Agricultural Technology: A Guide for Survey Design. Mexico, D.F.: CIMMYT. Retrieved from: https:/ / repository.cimmyt.org/bitstream/handle/10883/895/42412.pdf

Daykin, A., \& Moffatt, P. (2002). Analyzing ordered responses: A review of the ordered probit model. Understanding Statistics, 1(3), 157-166.

Ebojei, C., Ayinde, T., \& Akogwu, G. (2012). Socio-economic factors influencing the adoption of hybrid maize in Giwa local goverment area of Kaduna State, Nigeria. The Journal of Agricultural Science, 7(1), 23-32.

Feder, G., Just, R. E., \& Zilberman, D. (1985). Adoption of agricultural innovations in developing countries: A survey. Economic Development and Cultural Change, 33(2), 255-298.

Gebregziabher, G., Giordano, M., Langan, S., \& Namara, R. (2014). Economic analysis of factors influencing adoption of motor pumps in Ethiopia. Journal of Development and Agricultural Economics, 6(12), 490-500.

Greene, W. H. (2008). Econometrics Analysis. UpperSaddle River, New Jersey: PrenticeHall. 
Joffre, O. M., Bosma, R. H., Bregt, A. K., van Zwieten, P. A., Bush, S. R., \& Verreth, J. A. (2015). What drives the adoption of integrated shrimp mangrove aquaculture in Vietnam?. Ocean \& Coastal Management, 114, 53-63.

Kansiime, K. M., Shisanya, A. C., \& Wambugu, K. S. (2014). Effectiveness of technological options for minimising production risks under variable climatic conditions in eastern Uganda. African Crop Science Journal, 22(S4), 859-874.

Kassa, B., Kassa, B., \& Aregawi, K. (2014). Adoption and impact of agricultural technologies on farm income: Evidence from Southern Tigray, Northern Ethiopia. International Journal of Food and Agricultural Economics, 2(4), 91-106.

Liu, Y., Huang, J., Wang, J., \& Rozelle, S. (2008). Determinants of agricultural water saving technology adoption: An empirical study of 10 provinces of China. Ecological Economy, 4, 462-472.

Maonga, B., Assa, M., \& Haraman, E. (2013). Adoption of small metallic grain silos in Malawi: A farm level cross-sectional study. International Journal of Development and Sustainability, 2(2), 1534-1548.

Mazvimavi, K., \& Twomlow, S. (2009). Socialeconomic and institutional factors influencing adoption of conservation farming by vulnerable household in Zimbabwe. Agricultural System, 101(1-2), 20-29.

Van Thanh, N., \& Yapwattanaphun, C. (2015). Banana farmers' adoption of sustainable agriculture practices in the Vietnam uplands: The case of Quang Tri Province. Agriculture and Agricultural Science Procedia, 5, 67-74.

Ralm, M., \& Huffman, W. (1984). The adoption of reduced tillage: The role of human capital and other variables. American Journal of Agricultural Economics, 66(4), 405-413.

Saint-Macary, C., Keil, A., Zeller, M., Heidhues, F., \& Dung, P. T. M. (2010). Land titling policy and soil conservation in the northern uplands of Vietnam. Land Use Policy, 27(2), 617-627.

Saka, J., \& Lawal, B. (2009). Determinants of adoption and productivity of improved rice varieties in Southwestern Nigeria. African Journal of Biotechnology, 8(19), 4923-4932.

Sarker, A., Itohara, Y., \& Hoque, M. (2009). Determinants of adoption decisions: The case of organic farming in Bangladesh. Extension Farming Systems Journal, 5(2), 39-46.

Simelton, E. S., Catacutan, D. C., Dao, T. C., Dam, B. V., \& Le, T. D. (2017). Factors constraining and enabling agroforestry adoption in Viet Nam: A multi-level policy analysis. Agroforestry Systems, 91(1), 51-67.

Simtowe, F., Kassie, M., Diagne, A., Asfaw, S., Shiferaw, B., Silim, S., \& Muange, E. (2011). Determinants of agricultural technology adoption: The case of improved pigeonpea varieties in Tanzania. Quaterly Journal of International Agriculture, 50(4), 325-345.

Statistical Office of Province Lam Dong. (2018). Socio-economic Facts of Province Lam Dong in 2017. Lam Dong, Da Lat City: Statistical Office of Province Lam Dong. 
Sunding, D., \& Zilberman, D. (2001). The agricultural innovation process: Research and technology adoption in a changing agricultural sector. In B. Gardner, \& G. Rausser (Eds.), Handbook of Agricultural Economics (pp. 207-261). New York: Elsevier Science B.V.

Tiwari, K., Sitaula, B., Nyborg, I., \& Paudel, G. (2008). Determinants of farmers' adoption of improved soil conservation technology in a middle mountain watershed of Central Nepal. Environmental Management, 42(2), 210-222.

Wollni, M., Lee, D. R., \& Thies, J. E. (2010). Conservation agriculture, organic marketing, and collective action in the Honduran hillsides. Agricultural Economics, 41(3-4), 373-384.

Yengoh, G., Ato, A., \& Svensson, M. (2009). Technology adoption in small-scale agriculture: The case of Cameroon and Ghana. Science, Technology and Innovation Studies, 5(2), 111-131. 